\title{
Seasonal Variation of Dolphinfish Stocks (Coryphaena hippurus) in the Pacific Coast of Colombia
}

\author{
Ricardo Téllez and Susana Caballero* \\ Laboratorio de Ecología Molecular de Vertebrados Acuáticos-LEMVA, Departamento de Ciencias Biológicas, Universidad de los Andes, Bogota, \\ Colombia
}

Submission: March 03, 2017; Published: June 01, 2017

*Corresponding author: Susana Caballero, Departamento de Ciencias Biológicas, Universidad de los Andes, Laboratorio de Ecología Molecular de Vertebrados Acuáticos LEMVA, Carrera 1 No 18A-10, Bogotá, Colombia, Email: sj.caballero26@uniandes.edu.co

\begin{abstract}
Large pelagic fish are characterized by large population sizes, high dispersal capabilities and cosmopolitan distributions, decreasing the chances for population structuring. Therefore, considering ecological factors that can influence gene flow is important to understand possible stock structure. For the dolphinfish (Coryphaena hippurus) migratory movements attributed to sea changing conditions have been documented in the Eastern Caribbean. In the Colombian Pacific there has been no evaluation of possible stock differentiation. In order to adequately answer this question, temporal scale must be taken into consideration since seasonal abundance of this fish occurs in the Pacific coast of Central and South America. Here we investigate possible seasonal variation of dolphinfish stocks via analyses of mitochondrial DNA sequence data and analyses of five microsatellite loci. A total of 128 specimens were sampled from the coast of Colombia between November 2010 and December 2011. Levels of genetic differentiation between all sampling dates (months) were analyzed by calculating pairwise FST in order to detect genetic heterogeneity in a temporal scale. These analyses suggested subtle population differentiation among samples obtained in the first months of the year (Nov-May) vs. samples from months in the mid part of the year (Jun-Oct). Additionally, the Bayesian assignment test showed that the higher value of $\mathrm{K}$ was for $\mathrm{K}=2$. Both analyses showed genetic heterogeneity in a temporal scale, suggesting the presence of possibly two different stocks in the Pacific Coast of Colombia along the year. As our data suggests there is an incursion of individuals into the Pacific of Colombia during the seasonal abundance peak of capture between the months of January and May. These results suggest that individuals collected in close dates of the year are significantly less different among them than individuals collected in dates far apart. Considering dolphinfish are moving in the Pacific and each country has not only different management strategies but a different total allowable catch, the combined numbers of total allowable catch may end reducing the entire fish population and threatening the stock size if the information of possible stock differentiation is not considered in local and regional management plans.
\end{abstract}

Keywords: Dolphinfish; Coryphaena hippurus; Fish stocks; Pacific ocean; Microsatellites; Mitochondrial DNA

\section{Introduction}

Fish, like most marine resources, are increasingly growing to depletion due to intensified overfishing [1]. Therefore, it has become necessary to define the most appropriate way to manage fisheries in a sustainable way using both genetic and ecological approaches. In this sense, management of wild fisheries should be considered as a main priority in order to ensure that local fisheries can continue to be exploited in the long run [2]. Moreover, if research is conducted to identify the species genetic and ecological characteristics, this information could then be used on the recovery of depleted stocks and management of healthy ones [3].

Biological stocks are defined as "an intraspecific group of randomly mating individuals with temporal and spatial integrity" [4]. However, in most cases, fishery managers tend to define stocks as fish co-occurring in the same fishing ground, without taking into consideration their genetic integrity. Identifying stocks as not simply co-occurring individuals in a given area at a specified time but as individuals sharing similar genetic and ecological characteristics provides insight into more effective management due to true biological stock assessment [5].

Genetic and ecological analyses have been useful as an unequivocal and objective tool for assessment of true biological stocks. This has been used recently in stock definition in some large, pelagic, migratory and widely distributed fishes such as the striped marlin (Kajikia audax), blue marlin (Makaira nigricans) and bluefin tuna (Thunnus thynnus) [6,7]. The biological attributes of these species include:

i) They form large spawning congregations,

ii) There is absence of apparent barriers to gene flow and

iii) They have an intrinsic ability for large-scale dispersal. 
From these characteristics, one would expect a lack of genetic structure in large marine pelagic fish including the later species. However, in a number of these species genetic studies have shown the existence of more than one genetic biological stock $[6,8,9]$. For example, in the bluefin tuna, Appleyard et al. [8] showed the existence of significant spatial heterogeneity within the Mediterranean Sea. Further research into these species, that have been assumed to form large panmictic populations and are the main objective for fisheries around the world, should be considered as a priority to define stocks to be used in fisheries management programs.

The dolphinfish (Coryphaena hippurus), also known as "dorado" or "mahi-mahi", is a cosmopolitan, migratory pelagic fish found in tropical and subtropical waters [10]. In the Northeast Pacific Ocean this species is distributed throughout the tropical region from the Equator to Baja California. As other such large pelagic fish, dolphinfish exhibits high growth rates, early maturity, short life span and capacity for releasing several successive batches of eggs [11]. These features should, in theory, reduce the possibility of developing genetic differences between populations. However, conflicting data suggest the existence of regional factors that may limit connectivity and promote genetic heterogeneity as has been previously found in studies on dolphinfish in the Eastern Tropical Pacific and Gulf of California $[12,13]$. For this reason, it is then important to correctly assess whether the Pacific population consists of a single panmictic population or if several discrete populations can coexist at local scales.

It has been demonstrated that dolphinfish exhibit seasonal abundance in different countries, which has been explained by a possible migratory movement along the Eastern Pacific Coast [14]. Migratory routes such as the one suggested for the Eastern Pacific Coast have been already proved in the Caribbean. Farrel [15] found structured movement patterns inferred from tagged individuals and by analyses of ecological niche modeling.

The seasonal abundance observed in different countries may be the result from movement patterns of dolphinfish in the Pacific. This seasonal abundance has been seen in countries like Costa Rica (Sept-February) and Ecuador (November-May). In Colombia the biggest peak in catch rate is between the months of January and April; yet dolphinfish individuals captures show higher catch rates starting in November. Dolphinfish are captured throughout the year, which implies there must be a local resident group in the Pacific Coast of Colombia [14]. Even if global studies on dolphinfish show lack of interoceanic differentiation [16], this does not necessarily imply that there are not locally and discrete populations along the Pacific Coast. In fact, a monthly population assessment may increase the potential for finding stock structure if the species exhibits temporally and spatially constrained demographic pulses [12].
Dolphinfish is considered an important fishery resource on the Pacific Coast of Colombia, being one of the dominant fish obtained from the artisanal and industrial fleet landings. It is considered the second most important resource on the Pacific Coast of Colombia after the snapper (Lutjanidae), and above sharks (Carcharhinidae). Although its annual catch contribution is less than that of tuna, its annual landings are between 300 and 600 tons, making it a valuable resource in Colombia [14]. Based on the seasonal movement patterns presented by dolphinfish in the Pacific Coast of Colombia and the genetic data obtained in this study, we were able to test two hypothesis regarding dolphinfish stock structure in the Pacific Coast of Colombia. These were:

i) Dolphinfish form relatively discrete populations (stocks) in this area or

ii) They all belong to a single panmictic population in the Pacific Coastal waters of Colombia where the fishery takes place.

In the specific case of dolphin fish, multiple fisheries compete to catch fish in different countries; therefore understanding the behavior of exploited fisheries is key in order to implement management strategies. In order to test these two hypotheses, we analyzed five microsatellite loci and two mitochondrial genes (NADH1 dehydrogenase subunit 1 (ND1) and cytochrome $b$ (cytb)) for 117 dolphinfish captured between November 2010 and December 2011, along the Pacific Coast of Colombia.

\section{Materials and Methods}

\section{Sample collection}

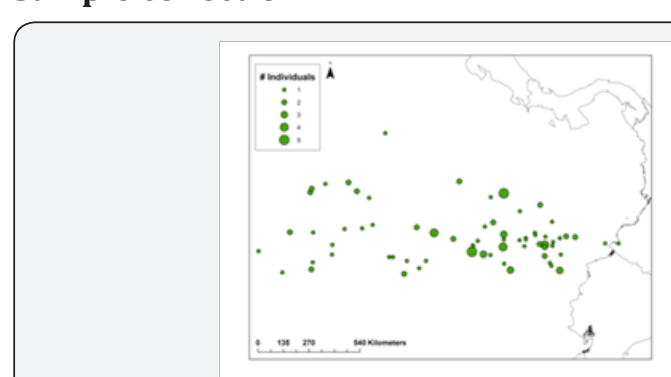

Figure S1: Sampling sites of the dolphinfish Coryphaena hippurus. Circle size represents the number of individuals collected in the same sampling point.

Samples of dolphinfish were collected in the Pacific Coast of Colombia over one consecutive year (2011) from small fishing boats operating in a local scale in the Pacific Coast of Colombia. Observers from the Instituto Colombiano de Desarrollo Regional (INCODER) collected muscle tissue samples (2g) from 128 dolphinfish between November 2010 and December 2011 (Supplementary material (SM); Figure S1). Tissue samples were preserved in $80 \%$ ethanol until DNA extraction. Accompanying data of the samples included GPS coordinates of the capture location, sex and size ( $\mathrm{cm}$ ) of the animal (Table S1). 
Table S1: Supplementary material.

\begin{tabular}{|c|c|c|c|c|c|c|}
\hline Sample ID & Collection Date & Latitude & Longitude & Size $\mathbf{c m}$ & Weight kg & Sex \\
\hline 3 & $\begin{array}{c}\text { November } 21 \\
2010\end{array}$ & 2.100 & 81.083 & & & M \\
\hline 5 & $\begin{array}{c}\text { November } 21 \text {, } \\
2010\end{array}$ & 2.100 & 81.083 & & & \\
\hline 10 & $\begin{array}{c}\text { November } 24 \\
2010\end{array}$ & 1.583 & 82.100 & & & M \\
\hline 11 & $\begin{array}{c}\text { November } 24 \\
2010\end{array}$ & 1.583 & 82.100 & & & $\mathrm{~F}$ \\
\hline 12 & $\begin{array}{c}\text { November } 25 \\
2010\end{array}$ & 1.733 & 82.350 & & & M \\
\hline 13 & $\begin{array}{c}\text { November 25, } \\
2010\end{array}$ & 1.733 & 82.350 & & & $\mathrm{~F}$ \\
\hline 15 & $\begin{array}{c}\text { November 29, } \\
2010\end{array}$ & 2.017 & 81.383 & & & \\
\hline 1 & December 1, 2010 & 3.600 & 82.317 & 98 & & \\
\hline 4 & December 1, 2010 & 3.600 & 82.317 & 99 & & \\
\hline 6 & December 6, 2010 & 2.767 & 84.550 & 99 & & \\
\hline 8 & December 8, 2010 & 2.767 & 84.550 & 98 & & \\
\hline 16 & $\begin{array}{l}\text { December 10, } \\
2010\end{array}$ & 4.250 & 91.050 & 93 & 8 & \\
\hline 17 & $\begin{array}{c}\text { December 10, } \\
2010\end{array}$ & 4.250 & 91.050 & 90 & 7 & \\
\hline 48 & $\begin{array}{c}\text { December 10, } \\
2010\end{array}$ & 1.767 & 78.583 & 120 & & $\mathrm{~F}$ \\
\hline 18 & $\begin{array}{c}\text { December 11, } \\
2010\end{array}$ & 2.300 & 94.233 & 92 & 7 & \\
\hline 19 & $\begin{array}{c}\text { December 11, } \\
2010\end{array}$ & 2.300 & 94.233 & 88 & 6 & \\
\hline 20 & $\begin{array}{c}\text { December 15, } \\
2010\end{array}$ & 5.567 & 96.783 & 91 & 7 & \\
\hline 80 & $\begin{array}{c}\text { December 17, } \\
2010\end{array}$ & 2.067 & 80.650 & & & \\
\hline 22 & $\begin{array}{c}\text { December 18, } \\
2010\end{array}$ & 4.367 & 93.200 & 100 & 10 & \\
\hline 23 & $\begin{array}{c}\text { December 18, } \\
2010\end{array}$ & 4.367 & 93.200 & 93 & 7 & \\
\hline 81 & $\begin{array}{c}\text { December 18, } \\
2010\end{array}$ & 2.067 & 80.650 & & & \\
\hline 82 & $\begin{array}{c}\text { December 18, } \\
2010\end{array}$ & 2.267 & 82.567 & & & \\
\hline 83 & $\begin{array}{c}\text { December 19, } \\
2010\end{array}$ & 2.017 & 83.000 & & & \\
\hline 84 & $\begin{array}{c}\text { December 19, } \\
2010\end{array}$ & 2.167 & 82.550 & & & \\
\hline 24 & $\begin{array}{c}\text { December 21, } \\
2010\end{array}$ & 1.883 & 85.283 & 115 & 12 & \\
\hline 25 & January 4, 2011 & 2.083 & 82.067 & 100 & & \\
\hline 56 & January 11, 2011 & 0.917 & 58.842 & 118 & & M \\
\hline 57 & January 11, 2011 & 0.917 & 58.842 & 91 & & $\mathrm{~F}$ \\
\hline 58 & January 12, 2011 & 1.167 & 82.100 & 116 & & M \\
\hline
\end{tabular}


Fisheries and Oceanography Open Access Journal

\begin{tabular}{|c|c|c|c|c|c|c|}
\hline 59 & January 12, 2011 & 1.167 & 82.100 & 111 & & $\mathrm{~F}$ \\
\hline 44 & January 14, 2011 & 2.267 & 87.367 & G & & \\
\hline 45 & January 14, 2011 & 2.267 & 87.367 & G & & \\
\hline 46 & January 15, 2011 & 2.533 & 88.200 & G & & M \\
\hline 47 & January 15, 2011 & 2.533 & 88.200 & G & & M \\
\hline 60 & January 21, 2011 & 0.317 & 88.800 & 116 & & M \\
\hline 61 & January 21, 2011 & 0.317 & 88.800 & 79 & & $\mathrm{~F}$ \\
\hline 26 & January 23, 2011 & 4.150 & 84.050 & & & \\
\hline 27 & January 23, 2011 & 4.150 & 84.050 & & & \\
\hline 28 & January 23, 2011 & 4.150 & 84.050 & & & \\
\hline 29 & January 23, 2011 & 4.150 & 84.050 & & & \\
\hline 30 & January 23, 2011 & 4.150 & 84.050 & & & \\
\hline 49 & January 29, 2011 & 2.650 & 90.300 & 82 & 5 & \\
\hline 31 & January 31, 2011 & 1.367 & 85.567 & & & \\
\hline 32 & January 31, 2011 & 1.367 & 85.567 & & & \\
\hline 33 & January 31, 2011 & 1.367 & 85.567 & & & \\
\hline 34 & January 31, 2011 & 1.367 & 85.567 & & & \\
\hline 35 & January 31, 2011 & 1.367 & 85.567 & & & \\
\hline 51 & February 2, 2011 & 1.700 & 92.217 & 108 & 10 & \\
\hline 42 & February 3, 2011 & 1.983 & 86.450 & & & \\
\hline 43 & February 3, 2011 & 1.983 & 86.450 & & & \\
\hline 37 & February 7, 2011 & 1.250 & 85.017 & & & \\
\hline 38 & February 7, 2011 & 1.250 & 85.017 & & & \\
\hline 39 & February 7, 2011 & 1.250 & 85.017 & & & \\
\hline 40 & February 8, 2011 & 4.717 & 86.167 & 80 & & $\mathrm{~F}$ \\
\hline 41 & February 8, 2011 & 4.717 & 86.167 & 60 & & $\mathrm{~F}$ \\
\hline 65 & March 1, 2011 & 0.867 & 93.150 & & 0.91 & \\
\hline 66 & March 2, 2011 & 0.533 & 93.217 & & 0.91 & M \\
\hline 67 & March 2, 2011 & 0.533 & 93.217 & & 1.36 & $\mathrm{~F}$ \\
\hline 68 & March 4, 2011 & 4.667 & 91.450 & & 2.27 & \\
\hline 69 & March 4, 2011 & 4.667 & 91.450 & & 2.27 & \\
\hline 70 & March 9, 2011 & 0.383 & 94.600 & & 1.81 & $\mathrm{~F}$ \\
\hline 71 & March 11, 2011 & 4.200 & 93.267 & & 1.81 & \\
\hline 72 & March 11, 2011 & 4.200 & 93.267 & & 1.81 & \\
\hline 73 & March 12, 2011 & 4.600 & 92.550 & & 1.81 & M \\
\hline 74 & March 14, 2011 & 7.017 & 89.700 & & 3.63 & M \\
\hline 75 & March 19, 2011 & 1.400 & 95.733 & & 1.36 & $\mathrm{~F}$ \\
\hline 76 & May 29, 2011 & 2.800 & 81.750 & 35 & & \\
\hline 77 & June 2, 2011 & 0.933 & 87.750 & 40 & & \\
\hline 62 & June 6, 2011 & 1.650 & 81.733 & 74 & 4 & \\
\hline 78 & June 9, 2011 & 2.283 & 93.133 & 100 & & \\
\hline 79 & June 12, 2011 & 3.933 & 90.467 & 100 & & \\
\hline 63 & June 17, 2011 & 1.767 & 79.217 & 90 & 8 & \\
\hline 64 & June 27, 2011 & 1.833 & 81.700 & 110 & 12 & \\
\hline 52 & July 2, 2011 & 0.700 & 81.783 & 80 & & \\
\hline 53 & July 7, 2011 & 1.950 & 84.050 & 50 & & \\
\hline
\end{tabular}


Fisheries and Oceanography Open Access Journal

\begin{tabular}{|c|c|c|c|c|c|}
\hline 54 & July 9, 2011 & 0.933 & 88.667 & 60 & \\
\hline 55 & July 10, 2011 & 1.117 & 89.517 & 60 & \\
\hline 118 & October 24, 2011 & 0.833 & 81.850 & 100 & $\mathrm{~F}$ \\
\hline 85 & October 25, 2011 & 1.233 & 81.333 & 102 & $M$ \\
\hline 100 & October 26, 2011 & 0.583 & 88.083 & & \\
\hline 86 & October 27, 2011 & 1.600 & 84.083 & 105 & $\mathrm{M}$ \\
\hline 87 & October 27, 2011 & 1.600 & 84.083 & 99 & M \\
\hline 88 & October 27, 2011 & 1.600 & 84.083 & 93 & $\mathrm{~F}$ \\
\hline 89 & October 27, 2011 & 1.600 & 84.083 & 91 & $\mathrm{~F}$ \\
\hline 119 & October 27, 2011 & 1.917 & 83.300 & 90 & $\mathrm{~F}$ \\
\hline 90 & October 28, 2011 & 2.200 & 84.050 & 105 & $\mathrm{~F}$ \\
\hline 91 & October 28, 2011 & 2.200 & 84.050 & 109 & $\mathrm{M}$ \\
\hline 92 & October 28, 2011 & 2.200 & 84.050 & 102 & M \\
\hline 101 & October 28, 2011 & 3.300 & 83.283 & & \\
\hline 120 & October 28, 2011 & 3.967 & 84.667 & 90 & $M$ \\
\hline 109 & October 30, 2011 & 5.717 & 106.317 & 100 & \\
\hline 110 & October 30, 2011 & 5.717 & 106.317 & 110 & \\
\hline 93 & November 3, 2011 & 1.233 & 92.233 & 84 & $\mathrm{~F}$ \\
\hline 97 & November 4, 2011 & 0.483 & 81.383 & & \\
\hline 98 & November 4, 2011 & 0.483 & 81.383 & & \\
\hline 99 & November 4, 2011 & 0.483 & 81.383 & & \\
\hline 121 & November 6, 2011 & 1.633 & 83.067 & 82 & $\mathrm{~F}$ \\
\hline 122 & November 7, 2011 & 2.567 & 84.950 & 82 & $\mathrm{~F}$ \\
\hline 102 & November 8, 2011 & 1.950 & 83.000 & & \\
\hline 123 & $\begin{array}{c}\text { November 10, } \\
2011\end{array}$ & 1.217 & 84.683 & 88 & M \\
\hline 94 & $\begin{array}{c}\text { November 14, } \\
2011\end{array}$ & 0.500 & 83.733 & 104 & $\mathrm{~F}$ \\
\hline 95 & $\begin{array}{c}\text { November 14, } \\
2011\end{array}$ & 0.500 & 83.733 & 106 & M \\
\hline 96 & $\begin{array}{c}\text { November 14, } \\
2011\end{array}$ & 0.500 & 83.733 & 90 & $\mathrm{~F}$ \\
\hline 103 & $\begin{array}{c}\text { November 21, } \\
2011\end{array}$ & 0.800 & 84.033 & 103 & $\mathrm{~F}$ \\
\hline 104 & $\begin{array}{c}\text { November 23, } \\
2011\end{array}$ & 1.667 & 85.517 & 93 & M \\
\hline 105 & $\begin{array}{c}\text { November 28, } \\
2011\end{array}$ & 1.650 & 85.500 & 109 & $\mathrm{~F}$ \\
\hline 111 & $\begin{array}{c}\text { November 30, } \\
2011\end{array}$ & 1.700 & 82.100 & 129 & \\
\hline 112 & $\begin{array}{c}\text { November 30, } \\
2011\end{array}$ & 1.700 & 82.100 & 108 & \\
\hline 113 & $\begin{array}{c}\text { November 30, } \\
2011\end{array}$ & 1.700 & 82.100 & 116 & \\
\hline 114 & $\begin{array}{c}\text { November 30, } \\
2011 \\
\end{array}$ & 1.700 & 82.100 & 107 & \\
\hline 106 & December 1, 2011 & 2.450 & 91.633 & 87 & $\mathrm{~F}$ \\
\hline 107 & $\begin{array}{c}\text { December 10, } \\
2011\end{array}$ & 2.083 & 87.367 & 66 & $\mathrm{~F}$ \\
\hline
\end{tabular}




\begin{tabular}{|c|c|c|c|c|c|c|}
\hline 108 & $\begin{array}{c}\text { December 10, } \\
2011\end{array}$ & 2.083 & 87.367 & 123 & F \\
\hline 116 & $\begin{array}{c}\text { December 17, } \\
2011\end{array}$ & 2.483 & 90.800 & 106 & \\
\hline 117 & $\begin{array}{c}\text { December 20, } \\
2011\end{array}$ & 1.117 & 89.333 & 91 & \\
\hline
\end{tabular}

\section{DNA data collection}

Mitochondrial gene regions: Genomic DNA was extracted following a phenol-chloroform protocol [17]. A 751 base pairs (bp) fragment of the NADH1 dehydrogenase subunit 1 (ND1) gene of dolphinfish was amplified using the primers NADH163 (5'-TAATCCTGCCGCAATTATCC-3') and NADH1128 (5'AGGCCTTCCAGGTTAGGT GT-3') designed by Díaz et al. [16]. PCR reactions were made up to a total volume of $30 \mathrm{ml}$ containing 10-100ng DNA. PCR amplification conditions consisted of 35 cycles of $1 \mathrm{~min}$ at $95{ }^{\circ} \mathrm{C}$ for denaturation, $1 \mathrm{~min}$ at $58.9{ }^{\circ} \mathrm{C}$ for annealing and a final extension at $74^{\circ} \mathrm{C}$ for 3 mins. A 500 base pair (bp) fragment of the cytochrome b (cytb) gene of dolphinfish was amplified using the internal primers (L14841 and H15149) [18]. Amplification reactions were made up to a total volume of $30 \mathrm{ml}$ containing 10-100ng of DNA. Amplification conditions consisted of 35 cycles of $2 \mathrm{~min}$ at $94{ }^{\circ} \mathrm{C}$ for denaturation, $45 \mathrm{sec}$ at $55^{\circ} \mathrm{C}$ for annealing and a final extension at $72{ }^{\circ} \mathrm{C}$ for $10 \mathrm{mins}$. Amplicons were purified with polyethylenglycol and sequenced on an ABI $3770 \mathrm{Xl}$ automated sequencer (Applied Biosystems).

Microsatellite genotyping: Five dolphinfish microsatellite loci registered in GenBank (Robert Chapman; South Carolina Department of Natural Resources, Charleston SC., unpublished) (Chi002, Chi008, Chi008a, Chi023 and Chi037) already used in dolphinfish [13] where amplified. Amplifications took place in $12,5 \mathrm{ml}$ reactions with the following concentrations: $1 \mathrm{x}$ buffer, $3 \mathrm{~mm} \mathrm{MgCl} 2,00.2 \mathrm{~mm} \mathrm{dNTP}, 0.003 \mathrm{~mm}$ of each primer and 0,002ul-1 Taq polymerase. The cycling profile consisted of an initial denaturing period of $2 \mathrm{~min}$ at $94^{\circ} \mathrm{C}$, five cycles at $94{ }^{\circ} \mathrm{C}$ for 5 s, annealing for $60 \mathrm{~s}$ at $59^{\circ} \mathrm{C}$ and extension for $60 \mathrm{~s}$ at $72{ }^{\circ} \mathrm{C}, 20$ cycles at $94^{\circ} \mathrm{C}$ for $0 \mathrm{~s}$, annealing for $60 \mathrm{~s}$ at $59^{\circ} \mathrm{C}$ and extension for $60 \mathrm{~s}$ at $72{ }^{\circ} \mathrm{C}$, and a final extension for $60 \mathrm{~min}$ at $59^{\circ} \mathrm{C}$. Products were run on an ABI3100 sequencer at Universidad de los Andes. Allele size was measured against an internal ladder (Tamra 500) using Gene Scan Analysis Software (1998). The binning of the microsatellite data was performed using the software TANDEM that uses a heuristic search with the Nelder-Mead Downhill Simplex algorithm and applies a least-square minimization of rounding errors to determine the allele number [19]. The program MICRO-CHECKER v. 2.2.3 [20] was used to determine the presence of null alleles, large allele dropout and scoring errors due to stutter peaks.
Data Analysis

\section{Mitochondrial DNA}

Sequences were aligned using Geneious Pro 3.6.1 [21] and edited manually. Unique haplotypes and variable sites were identified using MacClade v. 4.0 [22]. Haplotype (h), and nucleotide $(\pi)$ diversities were estimated with Arlequin 3.0 [23]. Hierarchical genetic structure of the samples was undertaken by assessing the relative contribution among groups, within groups, and within populations (AMOVA) using Arlequin 3.0 [23]. For this, we specifically tested the hypothesis based on the seasonal abundance peak, which considers individuals sampled between Dec and April (seasonal abundance peak) vs individuals sampled between May and Oct. 10,000 permutations.

\section{Microsatellite loci}

Levels of genetic diversity, expressed in number of alleles (NA), observed heterozygosity ( $\mathrm{H} 0$ ) and expected heterozygosity (HE) were obtained for each locus. Testing for deviations from Hardy-Weinberg equilibrium was performed using the software Arlequin 3.0 [23]. The null hypothesis of independence between loci (no linkage disequilibrium) was tested using the same software.

Levels of genetic differentiation between all sampling dates (months) were analyzed by calculating Wrigth's pairwise FST and the D estimate (actual differentiation of Jost 2008) was calculated with SMOGD [24]. A global AMOVA test including all samples was conducted to obtain the global FST value. Hierarchical genetic structure of the samples was undertaken by assessing the relative contribution among groups, within groups, and within populations (AMOVA) using Arlequin 3.0 [23]. For this, we specifically tested the hypothesis based on the seasonal abundance peak, which considers individuals sampled between Dec and April (seasonal abundance peak) vs individuals sampled between May and Oct. 10,000 permutations.

A Bayesian approach for assignment of individuals into stock was performed using the software Structure 2.3.1 [5,7,25] to complement the results obtained with F statistics. The admixture model and correlated allele frequencies between populations was selected. The Markov Chain Montecarlo (MCMC) consisted of 100000 steps with a burn-in period of 25,000 steps. We explored a range of $K$ from one to seven with six runs for each K-value. The appropriate number of clusters $(\mathrm{K})$ was selected using the 
criterion of Evanno [26] using the STRUCTURE HARVESTER v0.56.3 software [27]

\section{Results}

\section{Mitochondrial DNA}

Genetic diversity: A 525bp segment of ND1 gene was sequenced for 67 dolphinfish. A total of 61 variable sites defined 33 haplotypes. Haplotype diversity averaged $\mathrm{h}=0.9109$, and nucleotide diversity averaged $\pi=1.31 \%$. For Cyt $b$ a 345 base pair segment was sequenced for 78 dolphinfish. A total of 131 variable sites defined 35 haplotypes. Haplotype diversity averaged $\mathrm{h}=0.9108$ and nucleotide diversity averaged $\pi=1.87$ $\%$. Haplotype frequencies per month for Cytb (Table 1) and ND1 gene (Table 2) showed that between the months of December to February, during the seasonal abundance peak in Colombia [14], a higher total number of haplotypes was found. For cytb the most frequent haplotypes during these months were dorA, dorB, dorC and dorD. From these, only haplotypes dorA, dorB and dorC were also found in samples collected in October, November and December 2011 when the seasonal abundance peak started again. Three unique haplotypes were reported for June and July, months in which the catch rate is severely reduced. These unique haplotypes were not present at any other time during the year. For ND1 the most frequent haplotypes between the seasonal abundance months were dorA and dorD. Together with dorB, C, D, E, F and G they were only present between the months of December to March. Two unique haplotypes were reported as well for Jun and July. ND1 and Cyt $b$ haplotypes defined in this study were submitted to Genbank.

Table 1: Cytb haplotype frequencies.

\begin{tabular}{|c|c|c|c|c|c|c|c|c|c|c|c|c|c|c|}
\hline & \multicolumn{2}{|c|}{2010} & \multicolumn{12}{|c|}{2011} \\
\hline & Nov & Dec & Jan & Feb & Mar & Apr & May & Jun & Jul & Aug & Sept & Oct & Nov & Dec \\
\hline dorA & 2 & 2 & 5 & & 1 & & & & & & & 1 & & \\
\hline dorB & & 3 & 6 & 3 & 3 & & & 1 & 1 & & & & 1 & \\
\hline dorC & 1 & 2 & & & 3 & & 1 & & & & & & & \\
\hline dorD & 1 & 1 & 1 & & & & & 1 & & & & & 1 & \\
\hline dorE & & & & 1 & 1 & & & & & & & & & \\
\hline dorF & & & & 2 & & & & & & & & & & \\
\hline Total & 4 & 8 & 12 & 6 & 8 & & 1 & 2 & 1 & & & 1 & 2 & \\
\hline
\end{tabular}

Additional haplotypes represented by only one individual per month; for 2010 (Nov:1, Dec:7), for 2011 (Jan:6, Feb:2, Mar:3, Jun:2, Jul:1).

Table 2: ND1 haplotype frequencies.

\begin{tabular}{|c|c|c|c|c|c|c|c|c|c|c|c|c|c|c|}
\hline \multicolumn{3}{|c|}{2010} & \multicolumn{12}{|c|}{2011} \\
\hline & Nov & Dec & Jan & Feb & Mar & Apr & May & Jun & Jul & Aug & Sep & Oct & Nov & Dec \\
\hline dorA & & 4 & 5 & 4 & 1 & & & & & & & & & \\
\hline dorB & 1 & & 1 & & & & & & & & & & & \\
\hline dorC & 1 & & 1 & & & & & & & & & & & \\
\hline dorD & 4 & 3 & 3 & 1 & 2 & & & & & & & & & \\
\hline dorE & & 1 & 1 & & & & & & & & & & & \\
\hline dorF & & & 2 & & & & & & & & & & & \\
\hline dorG & & & 2 & & & & & & & & & & & \\
\hline Total & 6 & 8 & 15 & 5 & 3 & & & & & & & & & \\
\hline
\end{tabular}

Additional haplotypes represented by only one individual per month; for 2010 (Nov:1, Dec:5), for 2011 (Jan:4, Feb:3, Mar:3, Jun:1, Jul:3, Oct:2,

Nov:3, Dec:1)

Genetic differentiation: Pairwaise FST comparison between sampled dates (months) for ND1 gene (Supplementary Material, SM; Table S2) showed small but significant differences between November 2010 vs March 2011, December 2010 vs June 2011 and June 2011 vs November and December 2011. These differences are mainly between those individuals captured during the high catch season (January-April) and the ones captured in the other months. Most of the total genetic variance was found within populations (FST $=0.042, \quad \mathrm{P}=0.049$ ). The hypothesis that genetic variation could be structured according to the seasonal abundance peak was not rejected $(\mathrm{FCT}=0.124$, $\mathrm{P}=0.032$ ). For the Cyt $b$ gene pairwaise FST comparisons (SM; Table S3) showed small and significant differences between November 2010 vs December 2010, December 2010 vs January 2011, and November 2010 vs May 2011. For Cyt $b$ gene the hypothesis considering the genetic variation could be structured according to the seasonal abundance peak was rejected. 


\section{Fisheries and Oceanography Open Access Journal}

Table S2: Pairwise values for FST below the diagonal and their respective P values above the diagonal for ND1 gene.

\begin{tabular}{|c|c|c|c|c|c|c|c|c|c|c|}
\hline & Nov & Dec & Jan & Feb & Mar & Jun & Jul & Oct & Nov & Dec \\
\hline Nov & & 0.523 & 0.378 & 0.991 & 0.009 & 0.081 & 0.739 & 0.072 & 0.162 & 0.351 \\
\hline Dec & -0.033 & & 0.703 & 0.991 & 0.838 & 0.027 & 0.982 & 0.586 & 0.423 & 0.369 \\
\hline Jan & 0.006 & -0.11 & & 0.991 & 0.207 & 0.081 & 0.991 & 0.36 & 0.477 & 0.279 \\
\hline Feb & 0.28 & 0.034 & 0.131 & & 0.477 & 0.27 & 0.288 & 0.252 & 0.198 & 0.135 \\
\hline Mar & $\mathbf{0 . 1 6 8}$ & -0.083 & 0.03 & 0.176 & & 0.099 & 0.198 & 0.991 & 0.081 & 0.09 \\
\hline Jun & 0.293 & $\mathbf{0 . 2 0 0}$ & 0.245 & 0.778 & 0.359 & & 0.081 & 0.324 & 0.018 & 0.018 \\
\hline Jul & -0.067 & -0.125 & -0.2 & 0.667 & 0.156 & 0.653 & & 0.207 & 0.91 & 0.369 \\
\hline Oct & 0.1 & -0.1 & 0.034 & -1 & -0.2 & 0.857 & 0.571 & & 0.279 & 0.1017 \\
\hline Nov & 0.025 & 0.016 & -0.013 & 0.475 & 0.22 & $\mathbf{0 . 4 9 0}$ & -0.138 & 0.244 & & 0.153 \\
\hline Dec & -0.003 & 0.006 & 0.023 & 0.333 & 0.22 & $\mathbf{0 . 3 4 4}$ & -0.005 & 0.219 & 0.073 & \\
\hline
\end{tabular}

Numbers in bold correspond to significant $F_{S T}$ values $(p<0.002)$. Underlined Nov and Dec correspond to 2010.

Table S3: Pairwise values fot FST below the diagonal and their respective $\mathrm{P}$ values above the diagonal, for Cyt $b$ gene.

\begin{tabular}{|c|c|c|c|c|c|c|c|c|c|}
\hline & Nov & Dec & Jan & Feb & Mar & May & Jun & Oct & Nov \\
\hline Nov & & 0 & 0.09 & 0.99 & 0.082 & 0.045 & 0.108 & 0.405 & 0.991 \\
\hline Dec & 0.108 & & 0.009 & 0.991 & 0.342 & 0.333 & 0.676 & 0.369 & 0.991 \\
\hline Jan & 3 & 0.060 & & 0.991 & 0.514 & 0.396 & 0.243 & 0.784 & 0.991 \\
\hline Feb & 4 & -0.755 & -0.412 & & 0.991 & 0.622 & 0.775 & 0.991 & 0.991 \\
\hline Mar & -0.204 & -0.264 & -0.114 & 0 & & 0.829 & 0.928 & 0.991 & 0.991 \\
\hline May & 0.115 & 0.009 & 0.009 & 0 & -0.145 & & 0.369 & 0.82 & 0.991 \\
\hline Jun & 0.039 & -0.053 & 0.007 & -0.783 & -0.282 & -0.052 & & 0.622 & 0.991 \\
\hline Oct & -0.001 & -0.062 & -0.074 & -0.429 & -0.322 & -0.099 & -0.96 & & 0.991 \\
\hline Nov & -0.547 & -0.825 & -0.714 & -1 & -1 & -0.75 & -0.884 & -1 & 0 \\
\hline
\end{tabular}

Numbers in bold correspond to significant $F_{S T}$ Values $(p<0.005)$.

\section{Microsatellites}

Results from micro-checker showed that null alleles were not present. The analysis showed no evidence or large allelic dropout or stuttering. On average, the observed heterozygosityz (HO) was lower than the expected heterozygosity (HE). The observed heterozygosity (HO) ranged from 0.85 to 1 and expected heterozygosity (HE) ranged from 0.85 to 0.94 (Table $3)$. The number of alleles at each locus ranged from fifteen to forty-two. No loci were found to be in linkage disequilibrium $(\mathrm{P}>0.05)$ and all five loci appeared to deviate from HardyWeinberg equilibrium. Only two loci (chi008 and chi023) were in HWE equilibrium after Bonferroni's correction (adjusted $\mathrm{P}$ value $=0.01$ )

Table 3: Summary statistics for five microsatellite loci in 128 samples of the dolphinfish Coryphaena hippurus.

\begin{tabular}{|c|c|c|c|c|c|c|c|}
\hline Sample & \multicolumn{7}{|c|}{ Locus } \\
\hline & & chi002 & chi008 & chi008a & chi023 & chi037 & Mean Population \\
\hline & & & & & & & 93 \\
\hline Colombia & N & 85 & 82 & 96 & 97 & 105 & 31.8 \\
\hline & NA & 15 & 32 & 33 & 37 & 42 & 0.9518 \\
\hline & HO & 0.976 & 1 & 0.968 & 0.958 & 0.857 & 0.9126 \\
\hline
\end{tabular}

Sample Size $(N)$ : Number of Alleles; $\left(N_{A}\right)$ : Observed Heterozygosity; $\left(H_{0}\right)$ : Expected Heterozygosity; $\left(H_{E}\right)$ : Hardy Weinberg Disequilibrium was observed for the five loci used in this study $(P>0.05)$.

Pairwise FST comparison between sampled dates (months) for microsatellites (SM; Table S4), showed significant differences between fish caught in Dec2010, January, February, March and July versus fish caught in November. Fish caught in November are still considered to be part of that time of the year where

the seasonal abundance peak has not begun. Likewise between February and October significant differences where observed. All these estimates were consistent with the D estimator. The AMOVA analysis revealed that most of the total genetic variance was found within populations (months) (FST=0.011, 
$\mathrm{P}=0.0009$ ) therefore the hypothesis that nuclear variation could be structured according to the seasonal abundance pattern was rejected (FCT $=-0.0024, \mathrm{P}=0.00587$ ). Such negative estimates should be interpreted as zero in the AMOVA [23]. Surprisingly July appeared to be significantly different from all other months.

Table S4: Pairwise values for $F_{S T}$ below the diagonal and harmonic mean estimates of $D$ (above diagonal) among dolphin fish samples.

\begin{tabular}{|c|c|c|c|c|c|c|c|c|c|c|c|}
\hline & Nov & Dec & Jan & Feb & Mar & May & An & Jul & Oct & Nov & Dec \\
\hline Nov & & 0 & 0.035 & 0.003 & 0.004 & 0 & 0.003 & 518 & 0.005 & 0.031 & 0 \\
\hline Dec & -0.009 & & 0.044 & 0.013 & 0.0096 & 0 & 0.006 & 0.484 & 0.004 & 0.012 & 0 \\
\hline Jan & 0.022 & 0.008 & & 0.072 & 0.094 & 0 & 0 & 0.333 & 0.039 & 0.065 & 0 \\
\hline Feb & 0.001 & 0 & 0.012 & & 0.001 & 0 & 0 & 0.341 & 0.035 & 0.099 & 0 \\
\hline Mar & -0004 & 0.012 & $0-000$ & -0.02 & & 0 & 0 & 0.188 & 0.0036 & 0.05 & 0 \\
\hline May & -0.048 & -0.014 & -0.018 & -0.0311 & -0.024 & & 0 & 0 & 0 & 0.003 & 0 \\
\hline An & 0.011 & 0021 & -0.001 & -0.009 & -0.026 & -0.084 & & 0.507 & 0.003 & 0.031 & 0 \\
\hline Jul & $\mathbf{0 . 0 9 9}$ & $\mathbf{0 . 0 8 4}$ & $\mathbf{0 . 0 5 8}$ & $\mathbf{0 . 0 7 2}$ & $\mathbf{0 . 0 4 8}$ & 0023 & 0.088 & & 0.51 & 0.498 & 0.547 \\
\hline Oct & 0.017 & 0.006 & 0.014 & $\mathbf{0 . 0 2 4}$ & -0.007 & 0.04 & 0.016 & 0.071 & & 0 & 0 \\
\hline Nov & 0005 & $\mathbf{0 . 0 2 0}$ & $\mathbf{0 . 0 1 4}$ & $\mathbf{0 . 0 2 2}$ & $\mathbf{0 . 0 1 7}$ & 0.038 & 0.003 & $\mathbf{0 . 0 9 1}$ & -0.002 & & 0 \\
\hline Dec & -0.015 & -0.017 & -0.001 & -0.022 & -0.019 & -0.012 & -0.006 & $\mathbf{0 . 0 7 5}$ & 0.007 & 0.008 & \\
\hline
\end{tabular}

Numbers in bold correspond to significant $F_{\text {ST }}$ values $(p<0.05)$

The assignment test analysis conducted in STRUCTURE for the Colombian samples showed the highest likelihood at a population structure of $\mathrm{K}=2$ which was then confirmed using the Evanno et al. [26] method. The peak in the distribution of $\mathrm{K}$ was found at $\mathrm{K}=2$ (Figure 2).

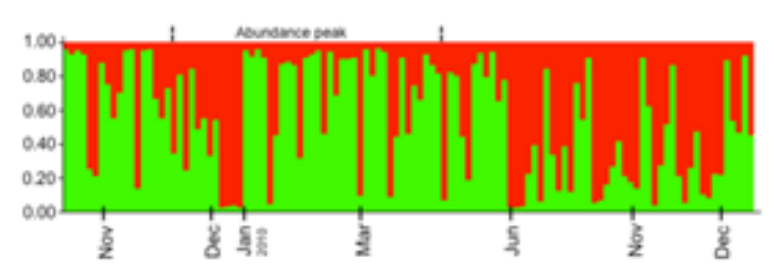

Figure 2: Bayesian assignment for each individual inferred by the program structure. Vertical lines indicate each of the individuals and the colors represent the probability membership coefficient of that individual to each genetic cluster.

\section{Discussion}

The degree of population differentiation has been related to the dispersal capacity of the species [28]. It has been recognized that species with higher dispersal capabilities show reduced levels of population differentiation [29]. This pattern has been observed in other large pelagic fishes such as tuna and billfishes $[6,8]$. Dolphinfish populations have been characterized by having great dispersal capabilities and effective population sizes similar to those observed in other pelagic fishes, as those estimated for bigeye tuna [30]. Large effective population sizes and great dispersal capabilities are biological attributes that may explain the reduced observed levels of population differentiation in dolphinfish [16]. The approach used in this study, taking into consideration the possible migratory capabilities observed in dolphinfish, has provided new insights into how dolphinfish populations are temporarily structured at least for populations found in the Pacific Coast of Colombia.

In this study we provide information about the genetic diversity and population structure of dolphinfish C. hippurus in the Pacific Coast of Colombia. Our analysis supports the hypothesis of the Pacific Coast of Colombia having two discrete temporally spaced stocks of dolphinfish, although at this time we have no evidence to define if individuals collected in distant months of the year belong to reproductively isolated units.

In this study we found high heterozygosity in the five loci analyzed ( $\mathrm{HE}=0.77$ ), this high levels of genetic variation have also been observed in dolphinfish [13] and in other large pelagic fish as big eye tuna [30]. The deviation towards heterozygous excess may be a result of mixing of two discrete isolated stocks, causing a temporary excess of heterozygotes. However, our data shows a clear tendency towards hardy-weinberg disequilibrium, perhaps as a result from the incursion of individuals from distant places, having a strong effect on the genetic composition of dolphinfish catches along the year in the Pacific Colombian Coast.

Both mitochondrial genes ND1 and cyt $b$ revealed a higher number of haplotypes during the seasonal abundance peak. This is in agreement with the higher number of individuals present during these months of the year, as has been suggested for dolphinfish catch records in the Pacific of Colombia [14]. Particularly for $c y t b$, the most frequent haplotypes during the catch peak between the months of January and April (dorA, dorB and dor C) were also present at Oct, Nov and December from 2011 when the seasonal abundance peak started again. This corroborates that the seasonal abundance peak starts in late November an lasts until April, as evidenced in catch records for 
dolphinfish [14]. For both ND1 and cytb unique haplotypes were present along the sampling period. Interestingly, there were also unique haplotypes for months when the catch rate is reduced. This would be suggestive of shared population history between stocks in the Eastern Pacific.

The change in allelic frequencies along the sampling year can be observed with the pairwise distance FST and the bayesian assignment test. Both analyses showed slight genetic heterogeneity in a temporal scale, suggesting the presence of possibly two different stocks in the Pacific Coast of Colombia along the year. Our results support there is a considerable change in allelic frequencies along the year, with low but significant (FST $=0.011, P=0.0009)$ values. As our data suggest there is an incursion of individuals into Colombian territory, during the seasonal abundance peak between the months of January and May [14]. This seasonal abundance in the Colombian Coast seems to be due to the arrival of dolphinfish individuals with different allelic frequencies as inferred with the Bayesian Assignment tests. Additional data from other Central (Mexico, Costa Rica and Panama) and South American countries (i.e. Ecuador) is necessary in order to infer and confirm the movement patterns of dolphinfish in the Pacific.

It has been demonstrated that dolphinfish move long distances in the Caribbean, as a result to changing sea surface temperature (STT). Moving southward during the colder months (August to February) and moving backwards to the Coast of Florida during the warmer months (May to July) [15]. In the Pacific Coast of Colombia dolphinfish possible migrations have been associated with thermal fronts forming in the Colombian Coast along the year. Also, the most persistent thermal fronts, where higher catch rate of dolphinfish have been reported, are more intense during the first two trimesters of the year (December-February and March-May) [31]. These months coincide with the peak of seasonal abundance of dolphinfish in the Pacific coast of Colombia. Considering this information, it is then plausible that dolphinfish stock dynamics in the Pacific are affected by similar factors such as the ones modeling the migration movements of this species in the Caribbean. Further research including satellite tagging would provide better understanding into the biology of this species in the Colombian Pacific.

A good scientific understanding of the behavior of the exploited stocks is prioritary in order to implement management strategies. Action plans should focus in maintaining sustainable fishery practices and targeting numerically robust stocks as a priority to implement global management plans where dolphinfish populations are included. For the Eastern tropical Pacific further research is needed in order to evaluate if the temporal stocks found in this study are migrating from neighboring countries, to prevent fishery depletion. Lack of knowledge and prevention produced the fishery decline of
Atlantic Bluefin tuna in Norwegian and German fisheries, where the lack of migration of mature tunas was explained by possible overfishing on local areas [32]. This is important information to be considered since dolphinfish populations also exhibit migration patterns and are targeted in different fishing grounds in many other countries in the Pacific (Mexico, Panama, Ecuador) [14].

For practical purposes, the direct conservation of particular alleles, or their frequencies would be almost impossible. Broader criteria as exploitation from numerically robust stocks, would reduce the impact on stock demographic dynamics, allowing the continuity of inter-stock exchange of genes and promoting this way the maintenance of high levels of abundance in all stocks [33]. In the specific case of dolphinfish, multiple fisheries compete to catch fish in different countries. Considering dolphinfish are moving in the Pacific and each country has not only different management strategies but a different total allowable catch (TAC), the combined numbers of TAC would end reducing the entire common-pool fishery and threatening the stock size [1]. Management authorities should seek a combined effort to reach sustainable fisheries

Although at this time we have no evidence to define if individuals collected in distant months of the year belong to reproductively isolated units, we suggest assigning the term "temporally defined stocks" to the population substructuring detected in this study. This information should be then considered before establishing a management plan for this fishery to ensure its long-term sustainability. Further research with a broader sampling and possible tagging methods might give a better understanding of the possible movement pattern of dolphinfish stocks in the Pacific.

\section{Acknowledgement}

We thank the INCODER (Colombian Institute for Regional Development) for providing dolphinfish samples. We also thank Carlos Mora for microsatellite running. Financial support for this project was provided by "Proyecto Semilla" and "Proyecto de Profesor Asistente" from Universidad de los Andes, Bogotá, Colombia.

\section{References}

1. Pauly D, Christensen V, Guenette S, Pitcher TJ, Sumaila UR, et al. (2002) Towards sustainability in world fisheries. Nature 418(6898): 689-695.

2. Beddington JR, Agnew DJ, Clark CW (2007) Current Problems in the Management of Marine Fisheries. Science. 316(5832): 1713-1716.

3. Youngson AF, Jordan WC, Verspoor E, McGinnity P, Cross T, et al. (2003) Management of salmonid fisheries in the British Isles: towards a practical approach based on population genetics. Fisheries Research 62(2): 193-209.

4. Ihssen PE, Booke HE, Casselman JM, McGlade JM, Payne NR, et al. (1981) Stock Identification: Materials and Methods. Canadian Journal of Fisheries and Aquatic Sciences 38(12): 1838-1855. 
5. Ward RD (2000) Genetics in fisheries management. In: Solé-Cava AM, Russo CM, Thorpe J (Eds.), Marine Genetics. Springer, Netherlands, 420(1): 191-201.

6. McDowell JR, Graves JE (2008) Population structure of striped marlin (Kajikia audax) in the Pacific Ocean based on analysis of microsatellite and mitochondrial DNA. Canadian Journal of Fisheries and Aquatic Sciences 65(7): 1307-1320.

7. Riccioni G, Landi M, Ferrara G, Milano I, Cariani A, et al. (2010) Spatiotemporal population structuring and genetic diversity retention in depleted Atlantic bluefin tuna of the Mediterranean Sea. Proceedings of the National Academy of Sciences 107(5): 2102-2107.

8. Appleyard S, Grewe P, Innes B, Ward R (2001) Population structure of yellowfin tuna (Thunnus albacares) in the western Pacific Ocean, inferred from microsatellite loci. Marine Biology 139(2): 383-393.

9. Carlsson J, McDowell JR, Díaz P, Carlsson JEL, Boles SB, et al. (2004) Microsatellite and mitochondrial DNA analyses of Atlantic bluefin tuna (Thunnus thynnus thynnus) population structure in the Mediterranean Sea. Mol Ecol 13(11): 3345-3356.

10. Palko BJ, Beardsley GL, Richards WJ (1982) Synopsis of the biological data on Dolphin-Fishes, Coryphaena hippurus Linnaeus and Coryphaena equiselis Linnaeus. NOAA Technical Report, NMFS(443), US Department of Commerce, NOAA National Marine Fisheries Service, Seattle, USA.

11. Oxenford HA (1999) Biology of the dolphinfish (Coryphaena hippurus) in the western central Atlantic: a review. Scientia Marina 63(3-4): 277301.

12. Rocha A, Bodailla M, Ortega S, Saavedra N, Sandoval JR (2006) Mitochondrial variability of dolphinfish Coryphaena hippurus populations in the Pacific Ocean. Ciencias Marinas 32(3): 569-578.

13. Tripp-VMA, García de LFJ, Ortega-GS, Lluch-CD, López-MJ, et al. (2010) Population genetic structure of dolphinfish (Coryphaena hippurus) in the Gulf of California, using microsatellite loci. Fisheries Research 105(3): 172-177.

14. Lasso J, Zapata L (1999) Fisheries and biology of Coryphaena hippurus (Pisces: Coryphaenidae) in the Pacific coast of Colombia and Panama. Scientia Marina 63(3-4): 387-399.

15. Farrel ER (2009) The Habitat, Movements, and Management of Dolphin Coryphaena hippurus, in the Western North Atlantic, Caribbean, and Gulf of Mexico. Environmental Management degree in the Nicholas School of the Environment, Duke University, USA.

16. Díaz-JP, Uribe-AM, Rocha-OA, García-de-LFJ, Nortmoon P, et al. (2010) Global phylogeography of the dolphinfish (Coryphaena hippurus): The influence of large effective population size and recent dispersal on the divergence of a marine pelagic cosmopolitan species. Mol Phylogenet Evol 57(3): 1209-1218.

17. Sambrook J, Fritsch EF, Maniatis T (1989) Molecular cloning: A laboratory manual. Cold Spring Harbor Laboratory Press, Woodbury, New York, USA.

18. Kocher TD, Thomas WK, Meyer A, Edwards SV, Paabo S, et al. (1989)
Dynamics of mitochondrial DNA evolution in animals: amplification and sequencing with conserved primers. Proc Natl Acad Sci USA 86(16): 6196-6200.

19. Matschiner M, Salzburger W (2009) TANDEM: integrating automated allele binning into genetics and genomics workflows. Bioinformatics 25(15): 1982-1983.

20. Van Oosterhout C, Weetman D, Hutchinson WF (2006) Estimation and adjustment of microsatellite null alleles in nonequilibrium populations. Molecular Ecology Notes 6(1): 255-256.

21. Drummond AJ, Ashton B, Buxton S, Cheung M, Cooper A, et al (2012) Geneious Basic: an integrated and extendable desktop software platform for the organization and analysis of sequence data. Bioinformatics 28(12): 1647-1649.

22. Maddison DR, Madisson WP (2000) MacClade 4: analysis of phylogeny and character evolution. Version 4.0. Sinauer Associates, Sunderland, Massachussets, USA.

23. Excoffier L, Laval G, Schneider S (2005) Arlequin (version 3.0): An integrated software package for population genetics data analysis. Evol Bioinform Online 1: 47-50.

24. Crawford NG (2010) smogd: software for the measurement of genetic diversity. Mol Ecol Resour 10(3): 556-557.

25. Graves JE (1998) Molecular insights into the population structures of cosmopolitan marine fishes. Journal of Heredity 89(5): 427-437.

26. Evanno G, Regnaut S, Goudet I (2005) Detecting the number of clusters of individuals using the software structure: a simulation study. Mol Ecol 14(8): 2611-2620.

27. Earl D, von Holdt B (2012) STRUCTURE HARVESTER: a website and program for visualizing STRUCTURE output and implementing the Evanno method. Conservation Genetics Resources 4(2): 359-361.

28. Graves JE, McDowell JR (2003) Stock structure of the worlds istiophorid billfishes: a genetic perspective. Marine and Freshwater Research 54: 287-298.

29. Ward RD (2006) The importance of identifying spatial population structure in restocking and stock enhancement programmes. Fisheries Research 80(1): 9-18.

30. Gonzalez E, Beerli P, Zardoya R (2008) Genetic structuring and migration patterns of Atlantic bigeye tuna, Thunnus obesus (Lowe, 1839). BMC Evol Biol 8: 252.

31. Selvaraj JJ, Guzman AI, Martinez A (2007) Thermal fronts and their influence on the distribution of Dolphinfish (Coryphaena hippurus) in the Pacific Coast of Colombia.

32. Fromentin JM, Powers JE (2005) Atlantic bluefin tuna: population dynamics, ecology, fisheries and management. Fish and Fisheries 6(4): 281-306.

33. Bowen BW (1999) Preserving genes, species, or ecosystems? Healing the fractured foundations of conservation policy. Mol Ecol 8(12 Suppl 1): S5-S10. 
This work is licensed under Creative Commons Attribution 4.0 Licens

DOI: 10.19080/OFOAJ.2017.03.555602
Your next submission with Juniper Publishers will reach you the below assets

- Quality Editorial service

- Swift Peer Review

- Reprints availability

- E-prints Service

- Manuscript Podcast for convenient understanding

- Global attainment for your research

- Manuscript accessibility in different formats

( Pdf, E-pub, Full Text, Audio)

- Unceasing customer service

Track the below URL for one-step submission https://juniperpublishers.com/online-submission.php 